\title{
A STUDY ON THE LOCAL DIAGNOSIS FROM THE CYTOLO. GICAL EXAMINATION OF THE SPUTUM
}

\section{By}

\author{
S. KIDOKORO AND N. KUSUMOTO
}

Sputum specimens from 110 patients with known diagnoses were examined. Papanicolaon stain smears were made and squamous epithelial cells, ciliated epithelial cells, aveolar epithelial cells, leucocytes, elastic filbers and others were studied.

In general, the cells appeared in the ${ }^{*}$ sputum seem $2 d$ to have some relations to anatomical location of the diseased areas.

In the pharyngo-laryngeal diseases, many flat cells were found and the other cells were scanty. In the tracheo-bronchial and pulmonary diseases, the differentiation was relatively difficult, and elasticfibers were seen in $62 \%$ in the later group but not in the former group.

It might be said that the cytological examinatin of the sputum should be used as a useful method in the diagnosis of diseases of the respiratory tracts.

喀痰の細胞検査 (Papanicolaou 染色) による病巣診断の検討

$$
\begin{aligned}
& \text { 三楽病院耳學咽啹科 }
\end{aligned}
$$

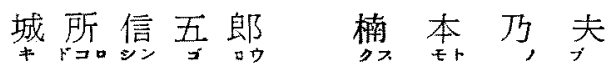

\section{1. 粕言}

血痰を主訴として訪れる患者は我が科領域に与いてを 少くないがその病巣を磪譛する事は決して容易ではな いのである・そこで，我々は気直の上皮細胞が部位によ り異つている事から，喀疾の Papanicolaou染色炕より， 細胞学的汇観察, 検討して, 血痰の病栄磪定汇役立せた いと考元て，喀痰の細胞出状態を調盗し，聊か，知見を 得たので報告する。

\section{2. 検査材料及び検查方法}

(1) 検省材料

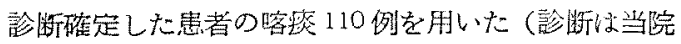
内科，耳鼻㸶䐅科にてなされた臨床診断を意味する）。

110 例中, 咽喉頭疾患（急・慢性咽喉頭炎）33 例, 気 管・気管交疾患 (急・慢性気管気管支炎) 30 例, 肺疾患 (結核, 膿㾝, 肺炎) 47 例，亏ち血痰は 28 例である.

（2）検笪方法

彷来喀痰の細胞検刑は Gimsa 染色がもつばら行われ
ていたが，近年 Papanicolaou 染色が癌細胞の診断に照 に用いられるに至り，その染色細胞が病理組織のそれに 近く, 細胞の特徽を活かすにおいて重要視されている点 に留意しこの実験に Papanicolaou 染色を応用したの である. 但し弾力線維については，上記染色では普通 線維との鑑別不充分につき，生の標本を用いている。

Papanicolaou 染洙染色法を次优べる.

1. アルコール・エーテル等量液にて 固定（10 分〜3 日間)。

2. $70 \%$ ファールに10回出没して通す.

3. $50 \%$ アルコールに10 回出没して通す

4. 蒸留水以 10 回出没して通寺

5. 階りス明攀へマトキシリンに3分浸す.

6. 流水党1分間通与

7. $0.5 \% \mathrm{HCl}$ 中に 5 回出没して通す

8. 流水を 4 分間通す

9. 炭酸リチウムに1 分間浸す 
10. 流水孛。分間道す。

11. $50 \%$ アルュール中に 10 回出没して通す

12. $70 \%$ アルュール中に10回出没して通す

13. $809 \%$ アコール中に10回出没して通す

14. $95 \%$ アルール中に10回出没して通す

15. オレンボ $G_{\text {i }}$ 中心 1 分間浸与

16. $95 \%$ アルール中に 10 回出没して通す

17. $95 \%$ アルニール中に 10 回出没して通す.

18. EA 36 中に 2 分間浸子.

19. $95 \%$ アンールに 10 回出没して通す

20. 無水アルュールに10 回出没して通す。

21. キシロールに通す

22. 封入.

23. 検鏡.

注甞 1. 喀㻬は早朝喀出されたのを用 5 事.

2. 喀痰1例につき，10数枚の䅺本を作る事.

3. 固定は24 時間が最毛よいので本検查炕は， 24 時間の固定をしている.

\section{3. 検査成績}

名喀察につき，10数枚の標本を作り，各々400倍㹡 大にて検鏡し，1視野中に認められる細胞数を全視野に ついて調疽し，1視野についての平均数を求め，それが

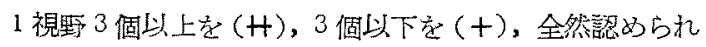
ないのを(一)として検悬成績をあらかした。

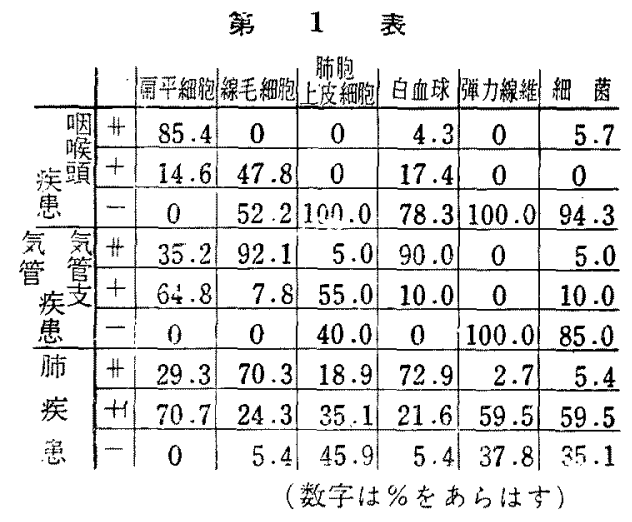

第に表に示したように，咽喉碩疾患では100\%に扁平 細胞が認められ，その量も多く(十)が $85.4 \%$ であり， 線毛細胞は $47.8 \%$ に認められ，量は屙平細胞と比較し て極めて少い，咽喉頭疾患に和いてはすべての視野に扁 平細胞が固つて多数現れるものが多く，他の細胞は殆ど

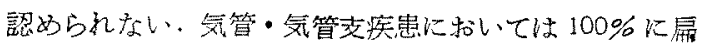

平細胞を認めるが、量は少く(H)の35.2\%に扎いてる 1 視野 3〜4 個程度のるの方過半数を占めている.

線毛細胞は $100 \%$ K認め，量も多く(H) 㔔92.1\% K 及んでいる・郝胞上皮細胞は60\%に諗められるが，量 は少く全視野 2〜3 個程度のものが過半数を占めている. 気篔・氮管支疾虫心肺胞上文細胞が出現する場合は，同 時に白血球が極めて多数認められ，臨床的に激しい㛺

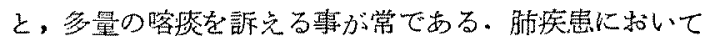

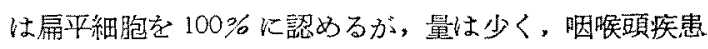
と合併している 2 例の例外に括いて極めて多数を認めた 以外仕 1 視野 $3 \sim 4$ 個程度である. 線毛細胞は94.6\% 認められ，量は積々の女のがある・肺胞上皮細胞は54\% に見られ，気管・気管支疾患の場合のごとき，臨床症 状, 白血球との関倸はない，前二疾患に諗められなかつ

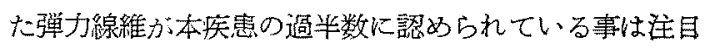
ずべき事であら。

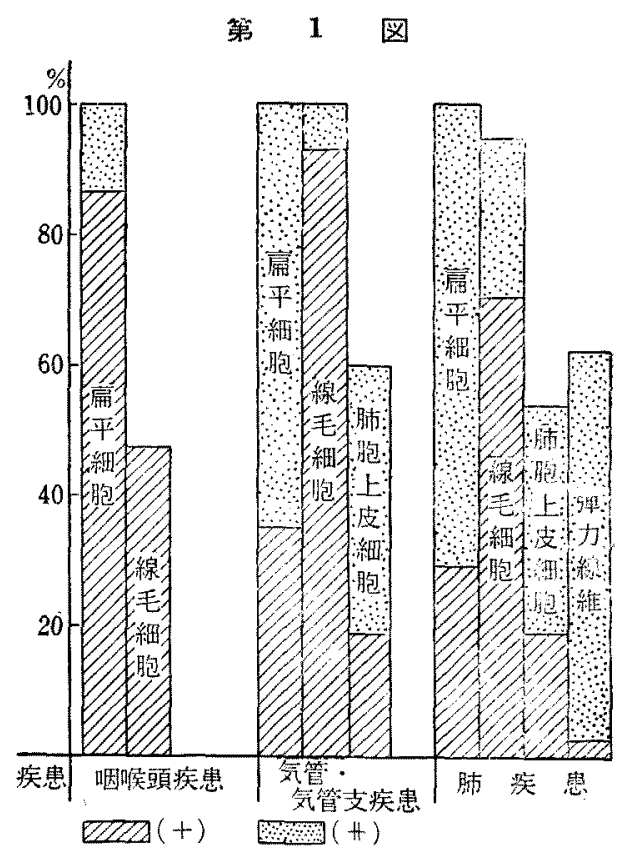

第1図は上記成績を゙图に示したものである。

\section{4. 考按及び総括}

以上の成綪と, 筑道の細胞分布との閔係を考察するた

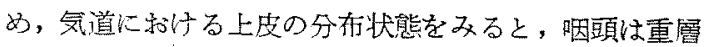

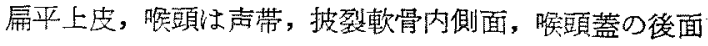
上部に病平上皮があり，他は多列楾毛上皮である、気管 気管支は多列線毛上皮であり，膜性壁にかずか厍平細胞 
城所楠本諭文附図

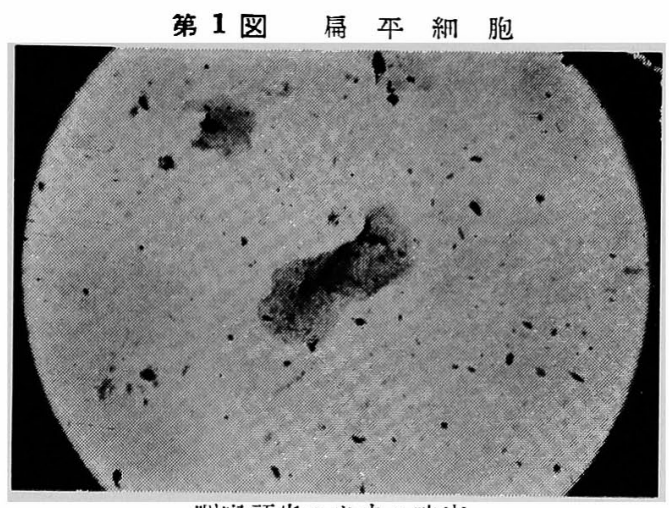

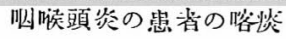

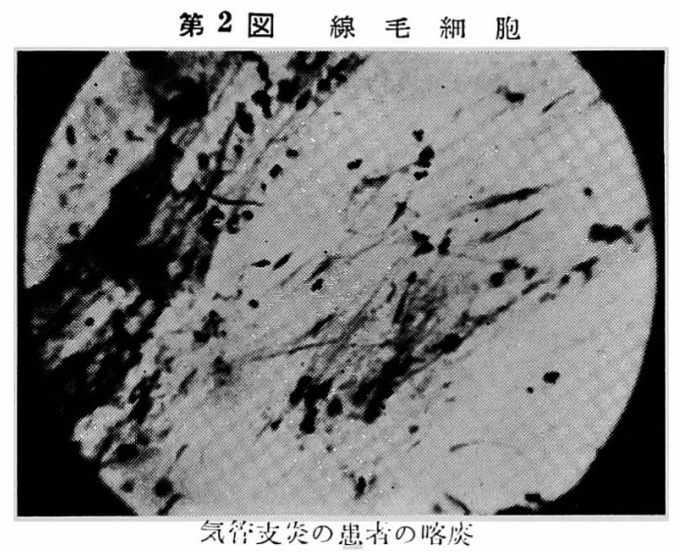

第3 図肺胞上皮細胞

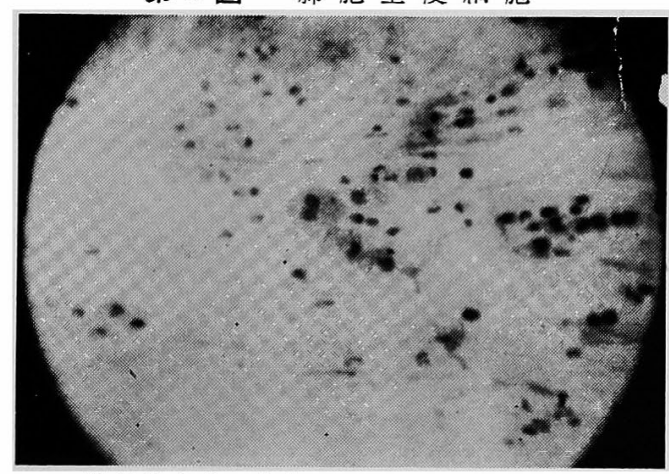

肺結核费者の喀炎で周囲に日血球が苛る 
上皮の部が散在している・肺胞は股子形細胞と無核板よ りなり，その直下に粗大並に微細な弾力線稚と血管に豊 んだ結合組織がある.気管支枝と肺との移行部は互に入 り混つていて，両者を明膫に境界つける事はできない。

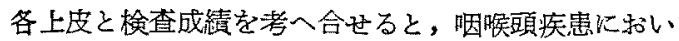
ては扁平細胞がいずれにも多数翟められ，その他，線毛 細胞，白血球がわずか少量認められている。一般に扁平 絈胞は剝離されやすく, 線毛細胞は上范に比して剝離さ れにくいと云われている、画者の占める面積, 気道とし ての刺战状態を考へ合せると, 扁平細胞が咽喉頭から喀 出される喀疾中に多量諗められる事が了承される. 従つ て咽倨頭疾患は他の二疾患から比較的容易に鑑別される のである・気管・気管支垁患と肺疾患との鑑別は比較的 困難であるが，これは気管支と肺との上皮境界が明磪を 欠きな絡各をが純粋に単独疾患である場合は少いた わ，細胞出現の比率関保が同者対称的でないからであ る.

本検查に括いて各ょ二疾患の場合を比較してみると， 扇平細胞ては両者共に $100 \%$ 存在し，量に䏡いても大差 はみとめられない，線毛細胞は気管・気管支疾患は 100 $\%$ に多量認められ，肺疾患は94.6\%に存し，量は前者

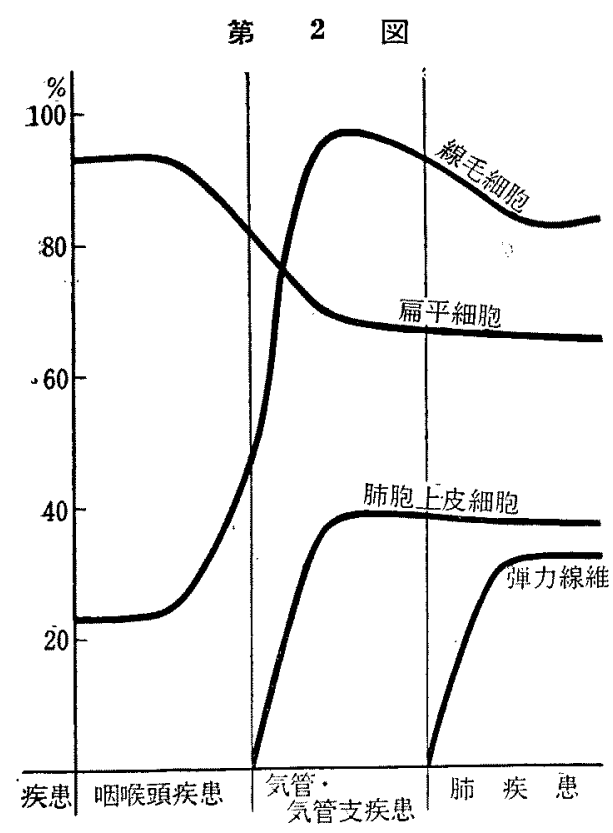

に比して少い，肺胞上細皮胞では\%に和いては大差はな いが，出現量は肺疾患の方が多く、気管・気管支疾患の 場合，この細胞の出現と共に多量の白血球の存在を認 わ, 多量の愘咨と激しい暖を認めている. 又肺疾患の場 合, 他の二疾患に認められなかつた弾力線維が $62 \%$ に 存在する.特にこの種の疾患の血痰には，すべてに，弾 力線維が認められている・しかし本検查に用いた血痰の

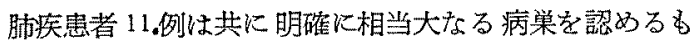
のばかりでるので，弹す線維が肺疾患者の血痰中に必 ず存在するとは考学られない，即ら軽淀の肺疾患者の血 桨中には存在しないかもしれないのである・しかし血管 と弾力線維が上皮直下の結合織内共存する事加ら血痖 の場合は普通喀疢に比して弾力線維が多量喀出されやす いのではないかと思う、以上，総括により，特徴を図示 立れば，第2図のよ弓で，喀痰の細胞出現状沇は解剖的 関係に関連をるつ事を知るもので，本検楂は上気道並に

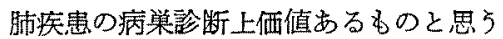

\section{5. 結語}

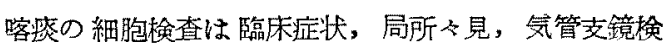
蒀、レントゲル所見等を併用して施行すれば，上気道並 に脯疾患において，有力な病巣の補助誩断法となし得る るのである事を認めた。

\section{6. 参考文献}

1) 足泣達：保健同人，8管，1是. 2) 石田二祁：

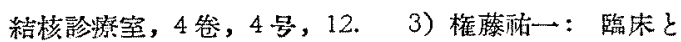

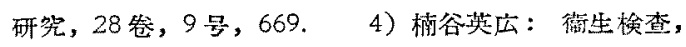

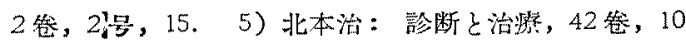
목, 927. 6) Bezancon, I. ahd Jong, S.J.: Traite del, examen des Crchats, Paris, 1913 (cited byWandall, 94). 7) Gloyne, S.R.: The cytology of the sputum, Tubercle $18 ; 292,1936$. 8) Von Hoesslin, H.: Das sputum, Berlin, 1926 (cited by Wandell 94). 9) Macklin, C.C.: Pulmonic alveolar epithelium, a roundtable conference $\mathrm{J}$. Thoracic Surg, 6;82, 1936. 10) Mavinow, A.A. and Bloom, $W$ : A textbook of Histology, Philadelphia, Saunders 1940. 11) Papanicolaou, G.N.: Diagnostic value of exfoliated cell. Jama, 131; 372, 1946.

（原精到㯰 $=1$ 㗁和 32.7 .12 日） 